\title{
Drug users hosting in a Basic Health Unit
}

\author{
Acolhimento de usuários de drogas em Unidade Básica de Saúde
}

\begin{abstract}
Daniel Goulart Rigotti ${ }^{1}$, Ana Paula Rigon Francischetti Garcia ${ }^{2}$, Natália Galvão Silva ${ }^{2}$, Thalita Mendes Mitsunaga ${ }^{2}$, Vanessa Pellegrino Toledo
\end{abstract}

Objective: to understand the care of drug users in a Basic Health Unit. Methods: a qualitative study through semi-structured interviews with 13 subjects in a Basic Care Unit of a health district. Results: after thematic analysis, three categories were revealed: Home as routing and factors that determine the practice, showing that factors such as feelings and personal characteristics of workers, lack of training and awareness of lower resoluteness by nursing professionals held a routing logic avoided accountability for the care, keeping its fragmentation; Host, link and routing, in which bond and co-responsibility were incipient practices, hindering the comprehensive care; and Home and predominant care models, showing that the host supported on the biomedical model, but contradictions were observed between different models and practices. Conclusion: it is necessary to overcome the biomedical model, from the expanded clinic and restructuring vocational training.

Descriptors: Mental Health; User Embracement; Drug Users; Primary Health Care.

Objetivo: compreender o acolhimento a usuários de drogas em uma Unidade Básica de Saúde. Métodos: estudo qualitativo realizado por meio de entrevistas semiestruturadas com 13 sujeitos em uma Unidade Básica de Saúde de um distrito de saúde. Resultados: após a análise temática, emergiram três categorias: Acolhimento como encaminhamento e fatores que determinam essa prática, evidenciando que fatores como sentimentos e características pessoais dos trabalhadores, falta de capacitação e percepção de menor resolutividade pelos profissionais de enfermagem sustentaram uma lógica de encaminhamento que evitava a responsabilização pelo cuidado, mantendo sua fragmentação; Acolhimento, vínculo e encaminhamento, em que vínculo e corresponsabilização eram incipientes nas práticas, dificultando o cuidado integral; e Acolhimento e modelos de atenção predominantes, mostrando que o acolhimento apoiava-se no modelo biomédico, porém observaramse contradições entre modelos distintos e práticas. Conclusão: faz-se necessário superar o modelo biomédico, a partir da clínica ampliada e da reestruturação na formação profissional.

Descritores: Saúde Mental; Acolhimento; Usuários de Drogas; Atenção Primária à Saúde.

${ }^{1}$ Prefeitura Municipal de Campinas. Campinas, SP, Brazil.

${ }^{2}$ Universidade Estadual de Campinas. Campinas, SP, Braszil.

Corresponding author: Vanessa Pellegrino Toledo

Faculdade de Enfermagem da Universidade Estadual de Campinas. Rua Tessália Vieira de Camargo, 126. Cidade Universitária Zeferino Vaz. CEP: 13083-970 - Campinas, SP, Brazil. E-mail: vtoledo@unicamp.br 


\section{Introduction}

Instituted by the 1988 Constitution and regulated by Law 8080/90, the Health System is intended to ensure access to comprehensive and equitable care in public health services ${ }^{(1)}$. It is constituted as a set of activities and services in health, which aims to promote a better quality of life, advancing the network consolidation of care areas and working by regions, hierarchical and integrated ${ }^{(1-2)}$.

The Basic Care is responsible for modeling the system resources, so that they respond appropriately to the country's health needs, through the Health Care Networks, which have in the Family Health Strategy a priority basis for its reorganization, since it provides significant expansion in the scope of assistance in this level of attention ${ }^{(2-3)}$.

Based on the socio-cultural model in which psychosocial rehabilitation arises as action strategy, the Family Health Strategy aims to overcome the biomedical, restrictive and little resolutive model, but still strongly rooted in the collective conceptions and individual health-disease and training workers ${ }^{(4-5)}$.

In the Basic Health Units, teams of the Family Health Strategy are structured. They are the preferred gateway to the Primary Care, to the inclusion and the start of treatment in the health system, as they are distributed in the community, with high permeability throughout the country, ensuring decentralization of health actions ${ }^{(2)}$.

In the routine care of the Basic Health Units, the practical application of the principles of Primary Care is guided by the National Humanization Policy, which aims to consolidate networks and establish links between the various actors in the system, aimed at co-responsibility between users, workers and managers by health care ${ }^{(6)}$. Its action transversely gives throughout the service network, consisting of individuals and collectives, articulating these assumptions and seeking to ensure the right of access to services and humanization in the care and management processes ${ }^{(6)}$.
In order to achieve these goals, the host was incorporated as one of the guidelines of the National Humanization Policy, understood as health staff attitudes that consider the needs of physical and psychosocial care to the operative attention to their problems, and also promote changes in the structure of the services of the Unified Health System ${ }^{(7-9)}$. In this context, the host drug users must also undergo a reorganization to promote decentralized and territorially actions, with increased access to these people and strengthening psychosocial rehabilitation ${ }^{(4)}$.

It is estimated that $12.0 \%$ of the population needs regular care due to problems associated with drug use, but there are obvious difficulties in the access of users to health facilities, the implementation and the effectiveness of preventive practices - priority for actions of the Primary Care ${ }^{(4,10)}$. This statement is corroborated in the increasing consumption of alcohol and other drugs, and the difficulties of health workers in detecting problems related to the consumption of these substances ${ }^{(4,11)}$.

The current health policies define the care of drug users in all equipment that makes up the Unified Health System network with different responsibilities and actions, according to their level of complexity. The Decree 3,088/11 established the Psychosocial Care Network, incorporating the principles of other health policies in force, to expand access to psychosocial care of the general population, promoting the link between people with mental disorders and drug users and their families, which should be articulated for comprehensive care(12-13).

As strategies to respond to this care model, the Psychosocial Care Network emphasizes the composition of teams, the relationship between the members of the network services, ongoing training of professionals, the shared management of the assistance and encouragement of participation of citizens in development and monitoring of the proposals set out in each territory ${ }^{(3,12)}$.

Recognizing that the Basic Health Unit 
integrates this care network, their actions with drug users, their families and the community in which it is inserted must then be guided by a proposal for psychosocial rehabilitation, according to which there must be respect for choices of the users and their uniqueness, seeking to assist in the construction of their citizenship ${ }^{(4)}$.

This study considers the host as a device that should ensure greater user access to health services, facilitating the establishment of relationships between workers and users through genuine listening to the demands and allowing conditions to produce reflections on the work processes in a perspective of comprehensive, humane and resolute care $\mathrm{e}^{(7-10)}$.

Given this panorama, this study aimed to understand the host drug users in a Basic Health Unit.

\section{Methods}

This was a qualitative study, carried out in a Basic Unit of North Health District of CampinasSP, Brazil. Data were collected in July 2013, through semi-structured interviews, because, while the interviewing technique allows respondents express their subjective impressions on the theme, it also guides the interviewer not to miss the focused goal of the interview, ensuring a certain freedom to further important aspects that arise during data collection ${ }^{(14)}$. The interviews used the following guiding question: "Have you received a user of psychoactive substances?" If so, it was asked: "How was it?"

The interviews were carried out by two medicine students previously trained, under the guidance of a psychologist Master's degree in Public Health at the workplace of the subjects, in offices that at that time were not being used for population assistance, with an average of 10 minutes. All interviews were recorded and transcribed in full.

The subjects of this research totaled 13 health professionals who performed the reception in the Basic Health Unit, identified by letters of the alphabet in sequence. Inclusion criteria were working in Basic
Health Unit scenario of research at the time of data collection and have already held host to drug users.

The number of study subjects was considered to unveil the phenomenon to the researcher, seeking to understand it, which is not necessarily proportional to some subjects, but the expression of the experiences of the participants about the acceptance of drug users ${ }^{(15)}$.

The Thematic analysis of data was held focusing on the following steps: (1) pre-analysis, to comprehensive reading of the transcripts, with a "floating reading" of interviews, performing a first separation and organization of the material produced in the field, in the sense of units grouped by similarities between them and their relevance, searching internal coherence; (2) exploration of the material, when it took care of rereading, making new and successive regroupings of subgroups from the connections perceived between units of meaning, coming finally to three categories (reception as routing and factors that determine this practice; host, link, and routing, and host and prevalent models of care); and (3) processing and interpretation of results based on the theoretical references and the mutual comparison with literature review $^{(14)}$.

The study complied with the formal requirements contained in the national and international standards of regulatory research involving human beings.

\section{Results}

In the Basic Health Unit studied, the host was developed exclusively by nursing professionals, and it was possible to unveil three categories presented below.

\section{Hosting as routing and the factors that determine this practice}

The findings of this study found the different behavior of professionals during the reception on the issues brought about by drug users, but all had to refer 
them to another professional purpose or the other team, under the influence of three determining factors for the host be performed as routing.

The first factor is the interference of the feelings that arose during and due to the host, and personal characteristics of the professionals: The patient can sometimes react in an unexpected way, do not like if his speech is not of him, understand? And it is like, little afraid to ask (G). Very sad because we do not have much to do with the patient, isn't it? There is not an immediate service to forward them; it is very difficult for me to refer this patient (E). I do not have much patience, well, not very much. I do not çike to assist them. If I have someone else who can do this part, I prefer (L).

The second factor was the need for professional training to meet this kind of demand, identified by the lack of discussion or specific courses to approach the drug user: Sometimes a training, a training course to develop more this theme. Perhaps a training, training, may improve (G). It is very little worked this issue of psychoactive substances, then you already come with a certain... no longer comes very prepared and here you do not have much, so training for this (L).

And finally, the third factor was the perception that their work had less resolution and efficiency than of mental health professionals: We refer to a psychologist, the therapist, the psychiatrist, who are professionals who give the ideal host for these patients (I). Then, after, with psychiatrists, there is a more comprehensive approach, if he is interested in treatment, follow-up or not, is more with the mental personal (K). I referred to a psychologist because they give a more private setting, they follow better (M).

\section{Host, link, and routing}

Another important finding was that the form of welcome did not favor the creation of links between professional and drug users: We now pass to the nurse who calls the doctor to give care; so we do not have many relationships with the patient, there, they already headed for the psychiatrist to psychologist (A). Give the routing according to what he wants, because he comes and asks 'I want it,' then we try to speed up what he is wanting $(\mathrm{B})$.
We observed that professionals headed bureaucratically without approach to user demand and the expected return of this referral: Give a follow-up, and not say 'do not even go with me, only forward, only guides to go to this address' and hence no one knows whether the patient if the patient was not, if you are using drugs even if it is not (A).

Also, we do not identify accountability for continued monitoring of the user when he was referred to another service: Dependent on alcohol, asking hospital help, and then I forwarded her to the Psychosocial Care Center because it had none of Mental Health, the psychologists or psychiatrists (C).

We also noticed that the drug user's health condition when arriving at the Basic Health Unit was crucial to the way it would give the host: Or sometimes happened that the patient gets convulsing here at the health center and go straight to the observation $(\mathrm{H})$. When they arrive in a state like, totally drunk, or drugged, they go straight to the observation, and not pass on the team. Sometimes it's an overdose, they go straight there, and we do not even have contact with them (B).

However, we also observed the perception of the host as the possibility of interaction, but impossible to perform if the user was intoxicated: They come in a crisis, we do more clinical intervention because usually we also cannot accept, so right, talk because he is in the midst of the crisis (L).

However, some speeches revealed practices that referral was made in a more involved way, but still not enough to overcome the biomedical model: I did a forward short letter to the Psychosocial Care Center ad, which has free time, she can come anytime she wants, I made a reference and explained a little of the case (C). We came with the case, is not it? We discuss cases with mental staff, but we do not accompany patients, is not it? Usually, they are forwarded to the mental personnel (K).

\section{Host and predominant care models}

Professionals have used more than one model to analyze the drug addiction situation, namely the biomedical and psychosocial. We observed this contradiction in all professional therapeutic practice 
during the reception, the initial approach to routing: Here we end up having to dispense patient because we do not have anything to do with him, has no medical book or doctors are on vacation in such period is very complicated (M). Something we realize that he is seeking help, support, something, a sense (G).

According to the biomedical model, we observed that the host gave priority to collecting clinical information for the question of the complaints and search for symptoms: But then you begin to ask some questions to diagnose or understand what is going on there at the moment $(\mathrm{H})$. Usually, we see the risk of the patient, examining the vital signs and then discussing with doctors $(\mathrm{K})$.

In this search for signs and symptoms, we note that the nursing staff tried to establish and follow a pattern of research during the reception, watching physical symptoms and making the registration of these signs, and prioritizing this last action: We only write down the symptoms he is feeling. What kind of drug he used, if it mixed with something else, drink. They usually arrive here sick with tachycardia symptoms as someone who used enough (A).

Also, there were attempts to address the demand with supply of drugs: They arrive with a complaint, we try to solve, go to the doctor, they go out from the doctor, take the medicine at the pharmacy from here, then they leave and go away (B).

Supported in the psychosocial model, we found reports that indicated the completion of reception where there was a willingness to listen, but still worried about identifying drug use: $S$, we have first to listen. Because they arrive already talking what they want. Then you listen to (D). We know it's user, the behavior, the family account, but they do not say they are users, or who came to seek help for this (M).

\section{Discussion}

The findings of this study found the different behavior of professionals during the reception of drug users and all had intended to refer them to another professional or team. Similar results have shown the host as a bureaucratic procedure, excluding and little related to the principles of comprehensiveness and universality, limited to the screening for insertion into scheduled agendas and not responding to subjective demands that were presented at that time ${ }^{(4,8,10)}$. Thus, they did not ensure compliance with the principle of the resolution and not full accountability function and ordering network, pointed by the current policy for primary care ${ }^{(1-2)}$.

As for the three factors that influence the host, leading to the practice of routing without coresponsibility, the first corresponds to feelings and personal characteristics of professionals, which may bring pain and induce a self-imposed limitation on the work of nursing professionals ${ }^{(10)}$.

Starting from the assumption that there is an inter-subjective relationship between the subjects in nursing care, it is considered that it is permeated by previous experiences of both and when it is facing a drug user, feelings like fear may arise in articulated professional prejudices built by the historical stigma of mental illness and may lead to a refusal to care, expressed by routing them ${ }^{(5,10,16)}$.

It was observed that the feelings which could produce greater understanding by the professional, their relationship with the user, become a spacer. Taking subjectivity as inherent work part could have the effect of relieving suffering, and produce conditions for the autonomy of professional and to qualify the host to care closer to health to policy guidelines supported the sociocultural model, and improve the quality of this relationship ${ }^{(10)}$.

The second factor corresponds to the need that the training of professionals to meet this kind of demand, showing that perception dates back to deficits in vocational training, namely the idea that nursing workers are not prepared to meet this specific demand, featuring the lack of technical training as one of the elements that may hinder access and attention to the demands of drug users ${ }^{(4,9-10)}$.

Even with the proposed changes to the under- 
graduate nursing curriculum in a more aligned approach to the design of comprehensive health, educational institutions still hold in their curricula the biomedical model, fragmented into specialties, which results in difficulties when entering the labor market organized by the guidelines of the Unified Health System ${ }^{(5,10,17)}$.

The continuing education of the professionals is a key strategy for tackling this problem by proposing the breakdown of barriers between the cores of knowledge, to produce other relationships between individuals, workers, and users, as protagonists in health care $^{(6)}$. This role could be achieved by encouraging the questioning of experiences of health workers, collectively, building contextualized strategies that align their policies and the unique reality of the territories and the subjects, which have the power to transform the reality of services and practices, the prospect of an upward action planning $^{(2,6,10)}$.

There is the need to provide undergraduate students to experience the daily services during the training period, bringing the future professionals a more realistic perspective of scientific knowledge and what is expected of him in practice services ${ }^{(5)}$. Also, historically, the constitution of nursing work occurs in a traditional training, which favors a subordinate culture to obscure the description of the assignments for each hierarchical level ${ }^{(16-17)}$.

In the hierarchical context of the relationship between the health professions, with overlapping of medical knowledge to others, the nursing agrees with the concept of empowerment as a synonym for shared power and promoting individual and collective transformation, encouraging reciprocity, creativity, expansion of knowledge and awareness ${ }^{(10,16,18)}$. The results of this study recognized that the need for training is linked to better conditions of empowerment, to develop a sustainable practice for the production of knowledge $\mathrm{e}^{(8,10,16)}$.

The third factor, realizing the mental health professionals as more resolute and effective than nursing, showed that nursing professionals do not recognize as their field effective search for solutions to the demands of drug users, delegating this responsibility to other professionals, who are considered by them as more competent to accommodate issues related to mental health ${ }^{(10)}$.

Adding to the factors of the subjectivity of professionals and insufficient training, this may also be due to the way the multidisciplinary team is constituted and operates in everyday life because we observed that the professionals of the host do not work seamlessly with the teams, as recommended by the Family Health Strategy ${ }^{(8-9)}$. This intends that the various professions share knowledge in an interdisciplinary perspective, and from there, producing new shares, to cover comprehensive care ${ }^{(2,18)}$.

The diversity of practices and knowledge of each professional core would be the scope for health care production more in tune with current policies, such as the Psychosocial Care Network. Thus, multi professionality not necessarily denote interdisciplinarity, because although bringing the advantage of increasing therapeutic possibilities, it can induce an installment process of care and fragmentation of work in services, abandoning the principle of comprehensiveness in Health Care, as observed in this study ${ }^{(1,17)}$.

One possibility to ensure the completeness and responsibility is the matrix support, as a strategy of Psychosocial Care Network, so there is circularity of the specific knowledge of each professional core - but that was not mentioned by any of the respondents as a resource for reorganization of its 
practice, despite being widespread in mental health of Campinas ${ }^{(3,12,17-18)}$. The support matrix provides that professional experts be in direct contact with the teams of primary care, in a horizontal relationship and together, establishing new action strategies for complex problems, providing technical assistance and support for the teams ${ }^{(17-18)}$.

Forwarding drug user without being responsible for him compromises the establishment of the bond, understood as a procurer for knowledge exchange that results in achieving therapeutic guided acts in the subtleties of each collective and each, promoting comprehensive care ${ }^{(19)}$. In this study, the user's voice appeared requesting a form, and the professional sought to meet the request made without a critical reading of the request. It is expected that professionals can have an attitude of understanding of context brought by establishing a dialogue to offering new significance $\mathrm{e}^{(7-8)}$.

Other than the recommended in the National Humanization Policy, the results showed that the professional disclaims of care responsibility when making routing without having exhausted the therapeutic and diagnostic possibilities present in the host, and preventing the user the co-responsibility, as it would expect ${ }^{(6-8,10-11,19)}$.

The construction of the link enables the user to have greater participation and autonomy in the process of decisions about their health, as this concept is characterized by the construction of affectivity relationships and trust between the user and the worker, which is directly linked to the relationship of co-responsibility for health ${ }^{(2,8,18)}$.

The results showed that if the drug user was intoxicated or in critical condition at the reception, this fact was decisive so that the host does not take place as envisaged in the study unit. More than the recognition of a momentary condition of the drug user that incapacitates for dialogue, the perception that the observation room and intoxicated user are incompatible with the practice of the host seems to support the understanding of the health-disease process, designed from the biomedical model.

Thus, we do not identify a share of the action, but isolated and disjointed attitudes, preventing care logic guided by comprehensive care and transdisciplinary ${ }^{(6,19-20)}$. As a result, health problems are treated in a fragmented and disconnected from the subject's experience, which does not provide the networking supported on the needs of users ${ }^{(8,13)}$.

Response to fragmented care is strengthening care lines, in which the central axis is the user and his singled therapeutic project, built from the perspective of his individual needs and network of clinical and social support, coordinated by the primary care team $^{(13,19)}$. The actions of various services, including cross-sector, if required, should be carried out in conjunction with a stream of references managed by the team of Basic Health Unit, constituting the lines of care, conforming non-hierarchical care networks built in everyday services agreements established between the subjects from the reality given in time of the meeting, which is characterized as a living work in action, weaving thus living networks ${ }^{(6,12-13)}$.

However, despite the behavior aimed primarily routing, avoiding any accountability, empathetic glances were observed. Empathy is understood as the ability to consider the subject and identify the emotions on the other, realizing the situation as if you were in the place of those who experience it. This attitude demand that the professionals perceive the explicit or contradictory manifestations of another's suffering trying not to allow their values to interfere in this process ${ }^{(10)}$.

The findings pointed to an empathic relationship that based professional accountability 
and training links between those involved in the process of receiving ${ }^{(9)}$. This would favor the sharing of care in its broader version, influencing positively in the care relationship. This multidimensional and comprehensive perspective of the subject characterizes the clinic expanded, as opposed to a clinical feature of the biomedical model, focused on signs and symptoms ${ }^{(20)}$. Thus, despite the strong influence of the biomedical model, we noticed the tendency of certain professionals in establishing the therapeutic practice in full(10).

The two models of care in action is supported in different theoretical and epistemological roots and unfold in contradictory methodological perspectives of intervention. The biomedical model can be influenced by the biopsychosocial concept of dependency, but the intervention grounded in this perspective becomes limited, to reduce the subject to his illness. But the psychosocial model emerges as a prerogative to enlarge the issues related to drug use in addition to the chemical variables. Its emphasis is on prevention and taking place in the drug user's context, seeking to modify their pattern of drug use, giving priority to control the damage arising from the use $\mathrm{e}^{(4)}$.

The speeches indicated a form of reductionist care and pathologizing drug user, with actions aimed at drug containment of symptoms, according to the biomedical model, and in line with the emphasis on this in psychiatry medicalization, bringing difficulties to the perception of the process multidetermined health-disease and render attention policies to current drug users in Brazil, with respect to the completeness, and the organization of care from the perspective of living network with the Psychosocial care network $^{(1,4,12)}$.

This treatment approach brings the discussion of health care humanization but does not overcome the fragmented dominant practice in the host that this procedure is considered, causing overload and feeling of the inability for professional ${ }^{(8,10)}$.

The contribution of this study permeates the need to reaffirm the challenge of facing the theoretical contradiction presented in the host between the training of professionals and proposals of public health policies, seeking the reassurance of comprehensiveness, the principle of the National Health System and the host, as a relationship between user and health worker producing subjects responsible for their own history. From these results, the exercise of expanded clinical and greater empowerment of nursing staff in the care management processes remain as challenges to be faced in the daily lives of the Basic Health Units.

\section{Conclusion}

This study identified that the way to make the host drug users in this Basic Health Unit has reduced to a procedure for nursing professionals, and confused with routing factors as feelings and personal characteristics of workers, lack of training for care to this specific population and a perception that mental health professionals would be more resolute and adequate that nursing produced a routing logic that avoids accountability for the care and continued fragmentation of health care.

The fragile empowerment has proved of nursing professionals in multidisciplinary teams and the effects of training still grounded in the biomedical model, which reproduces vertical modes and hierarchical professional relationship. There was a paradox between the limited availability for contact with the drug user by some professionals, and somelink establishment attempts to these users by others, from an empathic relationship, showing a contradiction in doing of the host of these professionals and hindering the establishment of care of living networks. 


\section{Collaborations}

Rigotti DG contributed to the design, analysis and interpretation of results and writing of the article. Silva NG and Mitsunaga TM contributed to the design, data collection, analysis, interpretation of results and writing of the article. Garcia APRF and Toledo VP contributed to.

\section{References}

1. Carvalho G. A saúde pública no Brasil. Estud Av. 2013; 27(78):7-26.

2. Ministério da Saúde (BR). Política Nacional de Atenção Básica. Brasília: Ministério da Saúde; 2012.

3. Mendes EV. 25 anos do Sistema Único de Saúde: resultados e desafios. Estud Av. 2013; 27(78):2734.

4. Schneider DR, Lima DS. Implicações dos modelos de atenção à dependência de álcool e outras drogas na rede básica em saúde. Psico. 2011; 42(2):16878.

5. Oliveira LRM, Carvalho CD, Carvalho CMS, Silva Junior FJG. O ensino da saúde mental para enfermagem: uma revisão da literatura. R Interd. 2013; 6(2):152-9.

6. Pasche DF, Passos E, Hennington ÉA. Cinco anos da política nacional de humanização: trajetória de uma política pública. Ciênc Saúde Coletiva. 2011; 16(11):4541-8.

7. Mitre SM, Andrade EIG, Cotta RMM. Avanços e desafios do acolhimento na operacionalização e qualificação do Sistema Único de Saúde na Atenção Primária: um resgate da produção bibliográfica do Brasil. Ciênc Saúde Coletiva. 2012; 17(8):2071-85.

8. Tintori JA, Helmo FR, Simões ACA, Resende L, Rodrigues LDPC, Goulart BF. The meaning and the practice of hosting for the workers of the family health strategy. Rev Enferm UFPE on line. [Internet]. 2014 [cited 2015 sep 05]; 8(5):11019. Avaliable from: http://www.revista.ufpe.br/ revistaenfermagem/index.php/revista/article/ view/5863/pdf_4985
9. Borges JDM, Silva LAA. The reception in basic health care: knowledge and practices. Rev Enferm UFPE on line. [Internet]. 2015 [cited 2015 sep 05]; 9(5):7887-94. Avaliable from: http://www. revista.ufpe.br/revistaenfermagem/index.php/ revista/article/view/6543/pdf_7824

10. Sucigan DHI, Toledo VP, Garcia APRF. Acolhimento e saúde mental: desafio profissional na Estratégia Saúde da Família. Rev Rene. 2012; 13(1):2-10.

11. Schneider JF, Roos CM, Olschowsky A, Pinho LB, Camatta MW, Wetzel C. Atendimento a usuários de drogas na perspectiva dos profissionais da estratégia saúde da família. Texto Contexto Enferm. 2013; 22(3):654-61.

12. Ministério da Saúde (BR). RAPS - rede de atenção psicossocial [Internet]. 2014 [citado 2015 ago 12]. Disponível em: http://portalsaude.saude. gov.br/index.php/o-ministerio/principal/ secretarias/803-sas-raiz/saude-mental/12saude-mental/12588-raps-rede-de-atencaopsicossocial

13. Quinderé PHD, Jorge MSB, Franco TB. Rede de atenção psicossocial: qual o lugar da saúde mental? Physis. 2014; 24(1):253-71.

14. Minayo MCS. O desafio do conhecimento: pesquisa qualitativa em saúde. São Paulo: Hucitec; 2014.

15. Martínez-Salgado C. El muestreo en investigación cualitativa. Principios básicos y algunas controversias. Ciênc Saúde Coletiva. 2012; 17(3):613-19.

16. Salvador PTCO, Alves KYA, Martins CCF, Santos VEP, Tourinho FSV. Reasons for empowerment in nursing: reflections in light of Alfred Schutz. Rev Min Enferm. 2013; 17(4):1014-25.

17. Medeiros CS, Carvalho RN, Cavalcanti PB, Salvador AR. O processo de (des)construção da multiprofissionalidade na atenção básica: limites e desafios a efetivação do trabalho em equipe na estratégia saúde da família em João Pessoa-PB. Rev Bras Ciênc Saúde. 2011; 15(3):319-28.

18. Cunha GT, Campos GWS. Apoio matricial e atenção primária em saúde. Saúde Soc. 2011; 20(4):96170 . 
19. Jorge MSB, Pinto DM, Quinderé PHD, Pinto AGA, Sousa FSP, Cavalcante CM. Promoção da saúde mental - tecnologias do cuidado: vínculo, acolhimento, co-responsabilização e autonomia. Ciênc Saúde Coletiva. 2011; 16(7):3051-60.
20. Campos GWS, Figueiredo MD, Pereira Júnior N, Castro CP. A aplicação da metodologia paideia no apoio institucional, no apoio matricial e na clínica ampliada. Interface Comun Saúde Educ. 2014; 18(Supl. 1):983-95. 